Likesom Paulus talte til en mann ved navn Dionysios på Areopagos-fjellet i Athen om den ukjente Gud, en Gud athenerne tilber uten å kjenne, så kan Derrida sies å ta utgangspunkt nettopp i en slik Gud: den Gud han ikke kjenner, som han heller ikke kan velge eller velge bort, en Gud han er kalt av, men påkaller i sokratisk uvitenhet.

\title{
Spor av død. \\ Spor av Gud Derridas tenkning på grensen mellom filosofi og religion
}

Er Gud den grunn vår tilværelse hviler på og garantien for at verden henger sammen? Eller er Gud en avgrunn for tenkningen - et mysterium som vi aldri kan begripe og derfor heller ikke ta for gitt at vi kjenner og forstår? Kan man overhodet være sikker på hva man refererer til når man tar ordet «Gud» i sin munn?

AV MARIUS TIMMANN MJAALAND
MED DISSE GRUNNLEGGENDE (eller avgrunnsåpnende) spørsmålene nærmer vi oss filosofen Jacques Derrida (1930-2004) og hans tanker om filosofi og religion. Allerede tidlig på 1960-tallet var Derrida opptatt av denne type spørsmål, men hadde ennå ikke innsett at de hadde noe med religion å

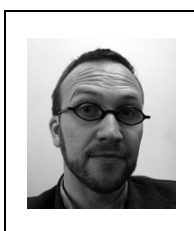

MARIUS TIMMANN MJAALAND (f. 1971) er postdoktor (NFR) på Teologisk Fakultet (UiO), leder av Kierkegaard-selskapet og for tiden president i European society for Philosophy of Religion. Dr. theol. i 2005 på en avhandling om Kierkegaard og Derrida. Boken Autopsia: Self, Death and God after Kierkegaard and Derrida utkommer på deGruyter Verlag i januar 2008.

516 MARIUS TIMMANN MJAALAND SPOR AV DøD. SPOR AV GUD 
gjøre. Han hevdet selv at han i denne perioden «med rette gikk for å være en ateist.» For ham dreide det seg nemlig om tenkningens opphav, om muligheten av erkjennelse og om forholdet mellom språk og fenomen. I Grammatologien (1967) hevder han at det ikke fins noe absolutt opphav til mening generelt. ${ }^{1}$ All vår erkjennelse er basert på forskjeller som forskyver og forandrer seg. Men som erkjennende vesener kan vi aldri komme bakenfor selve forskjellen, som går forut for vår bevissthet. Vi kan derfor ikke begrunne sann erkjennelse med en erfaring av at vi tenker (Descartes' cogito) eller et absolutt nærvær (Husserls transcendentale reduksjon). Det eneste vi kan erkjenne og forstå, er de spor som viser seg for vår bevissthet $\mathrm{i}$ erfaringer av noe annet og som vi så prøver å beskrive med språket.

\section{Skrift, død og galskap}

Et fenomen som «skrift» anskueliggjør hva dette dreier seg om: Skriften gir oss ingen direkte tilgang til hendelser, betydning og mening. Skrift er tegn som peker på noe annet, noe mer eller mindre betydningsfullt, men en betydning vi bare har indirekte tilgang til. Det gjelder selvfølgelig også for hellig skrift. Den viser hen til en annen tid, en annen virkelighet, men åpner seg kun for leseren gjennom skriftens spor. Dette får innflytelse på hvordan vi tenker om oss selv og om verden. Et litt merkelig eksempel som Derrida griper fatt i, er Descartes' frykt for å være gal eller for å være underlagt en ondsinnet Genius som forvirrer alle hans tanker. Som kjent løser Descartes problemet ved å ta sin tilflukt til tenkningens egen klarhet: Cogito ergo sum. Men Derrida peker på at han slett ikke overvinner galskapen på den måten - tvert imot tar han galskapen med seg inn i tenkningen og fortsetter å grunne over forskjellen mellom galskap og fornuft. Galskapens mulighet vil aldri kunne la seg utelukke på rent rasjonelt eller prinsipielt grunnlag. Grensen mellom galskap og fornuft er derfor en grense som går tvers gjennom tenkningen. Galskapen representerer dette fremmede, det andre, som vår rasjonelle evne aldri helt kan begripe, men heller aldri utelukke muligheten av.

Filosofi, hevder Derrida, er nettopp å beskjeftige seg med dette andre - i verden, i tenkningen og i språket. Tilsvarende er det med etikken: Det dreier seg alltid om den og de andre, som angår meg i sin annerledeshet. Det er det/ den andre som gir filosofien en retning og et innhold, ikke fordi en kan 
begripe det og tilegne seg det (dvs. gjøre det til ens «eget») - men fordi det forblir fremmed og annerledes, det forstyrrer meg i kraft av sin annerledeshet. På denne måten er det filosofien ifølge Derrida også nærmer seg døden eller Gud; som det andre, det som unndrar seg subjektets og tenkningens kontroll. Både døden og Gud er kjennetegnet ved at de unndrar seg en fenomenologisk analyse. De representerer dette helt andre - som en gjør tvetydige erfaringer med, ofte problematiske og vanskelige erfaringer - men som idet det «treffer» en, treffer i den grad et en blir drevet til å tenke over sporene og hva de betyr: Spor av død. Spor av Gud.

\section{Negativ teologi}

Da Derrida i 1969 hadde holdt et berømt foredrag om Différance, dvs. om forskjellen og forskyvningen mellom skrift og tale, ble han spurt om ikke det han drev med var en form for negativ teologi. ${ }^{2}$ Han svarte benektende, for han hadde slett ikke noen intensjon om å drive med teologi. Tvert imot hadde han selv avvist at teologien kunne gi noen løsninger på de filosofiske problemene han var opptatt av. Men i løpet av de neste 10-20 årene vender denne tanken tilbake i ulike former og han oppdager at mystikken og ulike «negative» teologer har drevet med ting som han selv er opptatt av - under et annet navn. Poenget med negativ teologi (f.eks. hos Dionysios Areopagita eller Meister Eckehart) er nettopp at språket ikke er i stand til å gi oss en god beskrivelse av hvem eller hva «Gud» er. Gud selv kommer aldri til syne for den erkjennende, han skjuler seg i mørket forut for enhver erkjennelse, lar seg kun ane i den tause bønnen som er uten ord.

Dette får radikal betydning for forståelsen av forholdet mellom språk og virkelighet. Tenker man Gud som opphav til alt som er, samtidig som man innrømmer at opphavet selv er uerkjennelig, så vil nettopp dette ubestemmelige knytte seg til erkjennelsen av ethvert objekt, ethvert subjekt, enhver sannhet og enhver sammenheng (årsak, ansvar, etc.) i tilværelsen forøvrig. «Gud» kan ikke tenkes løsrevet fra alt dette andre, ettersom det er «Gud» det skylder sin eksistens, det er i kraft av «Gud» det er hva det er. Dette prinsipielt ubestemmelige ved alt som «er» viser seg først og fremst i språket, som en forskyvning mellom ordet, den språklige betegnelse (signifiant) og det som språket setter ord på (dvs. det betegnede, signifié). ${ }^{3}$ Dionysios Areopagita (400-tallet) hevder i Den mystiske teologi at Gud verken kan sies å vore 
eller ikke vœre, verken lys eller mørke, verken bekreftelse eller benektelse, nettopp fordi Gud selv er forut for og hinsides disse menneskelige kategoriene, fornuftens forsøk på å begripe tilværelsen. Gud lar seg kun ane i den tause henvendelse som uttrykkes ved meditativ bønn - uten ord. Derav tittelen på Derridas essay: «Hvordan ikke tale. Benektelser» (Comment ne pas parler. Dénégations).

I analysen av Dionysios tar Derrida utgangspunkt i en forskjell (différance) i språket mellom slik det fungerer når det beskriver virkeligheten og slik det fungerer i bønnen. Også bønnens modus kan differensieres mellom (1) en åpen henvendelse og (2) en beskrivende lovprisning av guddommen. ${ }^{4}$ Nøkkelen til å forstå Dionysios, hevder han, ligger nettopp i den første, nemlig bønnens tillitsfulle henvendelse uten ord. Å tale om Gud er å tale uten å tale, dvs. å la Gud vare Gud - for å si det med Petter Dass - ved å innse sin egen uvitenhet om hva eller hvem Gud «er». Hvilket vil si at Gud er (i den grad han

Dette ubestemmelige ved Gud unndrar seg selv den kristne forståelse av Gud som treenig «er») den helt Andre. Dette ubestemmelige ved Gud unndrar seg selv den kristne forståelse av Gud som treenig, påpeker Derrida, og åpner derfor talen om Gud for ulike religiøse tilnærminger, ja faktisk for områder som slett ikke anses som religiøse, dvs. for mysteriet i den juridiske diskurs, i litteraturen, i etikken, i litteraturen - og i filosofien. En slik forskyvning av den teologiske diskurs kan leses på to måter: Enten som en utvidelse av teologiens relevans for en rekke andre fagfelt eller også som en profanisering og utvanning av det spesifikt teologiske ved teologien. Derrida har blitt kritisert for å gjøre begge deler - og antagelig med rette. ${ }^{5}$ Antagelig er det nettopp dette som er så nyskapende og tankevekkede ved hans ansats. Det provoserende med Derrida synes å ligge i nettopp dette at han gjør begge deler og fastholder at det er det han vil. Det ligger en spenning i dette som ikke skal oppheves eller bortforklares; man må tvert imot fastholde spenningen og utholde den for å ane noe om hvem eller hva Gud er - og hvordan enhver tekst vil måtte forholde seg tvetydig til Gud selv, også en tekst som går under navn av åpenbaring. 


\section{Gå dit du ikke kan gå}

Likesom Paulus talte til en mann ved navn Dionysios på Areopagos-fjellet i Athen om den ukjente Gud, en Gud athenerne tilber uten å kjenne, så kan Derrida sies å ta utgangspunkt nettopp i en slik Gud: den Gud han ikke kjenner, som han heller ikke kan velge eller velge bort, en Gud han er kalt av, men påkaller i sokratisk uvitenhet. Problemet for moderne eller postmoderne mennesker som han selv (som med rette gikk for å være ateist) er at de har vanskeligheter med selve navnet «Gud» og hva det skal bety. Religionskritikerne har «avslørt» det som en menneskelig projeksjon og hhv. Marx og Nietzsche har vist hvordan «Gud» utnyttes for å undertrykke bestemte klasser og opprettholde tradisjonelle makt- og kunnskapsregimer. Derrida har selv vanskeligheter med å forklare navnets betydning og motsetter seg enhver direkte forklaring. Kanskje, skriver han, er vi til og med nødt til å klare oss uten dette navnet (fransk: saufle nom) for å forholde oss til Gud. Paradoksalt nok kan dette «uten» også bli en måte å redde Guds navn på: (fransk: saufle nom! betyr også: redd navnet!). ${ }^{6}$

Derrida er vokst opp i en jødisk familie og denne måten å tenke om Gud på har klare jødiske røtter. I ortodokse jødiske miljøer har det helt siden før Jesu tid vært et forbud mot å uttale gudsnavnet JHWH. Nettopp ved $i k k e$ å uttale navnet beskytter man det mot misbruk, mot den illusjon at språket kunne romme Gud. Samtidig rommer navnet selv et løfte om en fremtidig oppfyllelse, av noe uventet som sprenger rammen for det sannsynlige og forventede. ${ }^{7}$ For å få del i løftet, skriver han, må du gå dit du ikke kan gå. ${ }^{8}$ Først hvis en oppgir sine vante kategorier, først hvis en våger seg ut i ørkenen eller tar imot den fremmede som en gest av gjestfrihet, aner en betydningen av å gi slipp på seg selv og åpne seg for det Annet. I denne gesten ligger det ikke bare en religiøs bevegelse, men også en politisk, som sprenger det religiøse systemet innenfra.

Det er konklusjonen Derrida trekker etter å ha lest diktere som Angelus Silesius og Meister Eckehart: Det fins en side ved religionen som er positivt historisk, som henger sammen med overlevering av dogmer og kontinuitet i tradisjoner, i kristen og jødisk sammenheng med eksplisitt referanse til en åpenbaring. Men det fins også en uovervinnelig negativitet i religionene, hos tenkere som er i stand til å overskride eller transcendere tradisjonen uten å fornekte den, men tvert imot lar den få en radikalt $n y$ betydning. ${ }^{9}$ En 
tenker som Meister Eckehart er på samme tid ortodoks kristen og radikalt nytenkende. Nettopp ved å sprenge en dogmatisk fastspikret tradisjon åpner han for en fornyelse av tradisjonen, både mot fremtiden og mot «de andre», mot dem som utelukkes og støtes ut fra det gode selskap.

Dette er idealet for det Derrida har kalt «religion uten religion»: Den radikale overskridelsen av tradisjonen innenfor tradisjonen innebærer på samme tid en indre og ytre omveltning eller revolusjon. Dette henger sammen med en absolutt transcendens (dvs. den absolutte ytterside) som kommer til orde fra innsiden. ${ }^{10}$ En tradisjon som vektlegger denne dobbeltheten vil i henhold til Derrida med nødvendighet måtte forandre seg for å bli seg selv lik. Den vil faktisk til enhver tid forbli fremmed for seg selv og $-\mathrm{i}$ oversettelsen fra et språk til et annet, fra en generasjon til den neste - gjennomgå en dyptgående forandring som fører den tilbake til opphavet.

\section{Adieu}

Er det slik at alle mennesker skal dø, så er dødens uvisshet betingelsen for å erkjenne livet

Derrida vender imidlertid ikke bare tilbake til opphavet, men også til døden. Hele forfatterskapet handler i en viss forstand om døden, men i døden, ved en grav, møtes da også disse to - opphavet og enden - i en siste hilsen: Adieu. Da en annen jødisk filosof, Emmanuel Levinas, døde i 1995 holdt Derrida en lang tale ved graven for sin lærer og venn. Den dreide seg om dette å ta adieu, å våge å uttale ordene, å tale til den døde, men også å gjøre dette med bevissthet om den dødes fravær og uforglemmelige nærvær. Nettopp dette tvetydige ved situasjonen er det som bringer tanken hen på Gud, på dette å slippe den annen løs og la ham gå - i bevissthet om at det uvisse og ubestemmelige ved døden svarer til det uvisse og ubestemmelige ved Gud. ${ }^{11}$ Det er dette som er å øve seg i å dø, dvs. å praktisere filosofi.

Når Sokrates hevder at filosofi er en øvelse i å d,${ }^{12}$ så henger det nemlig sammen med at døden angår ethvert menneske, men til enhver tid unndrar seg dets forståelse og kontroll. Er det slik at alle mennesker skal dø, så er dødens uvisshet betingelsen for å erkjenne livet. Men døden møter en som det tvetydige, det ubestemmelige. Ved døden må en gi slipp på kroppen og alt annet forgjengelig. Ved å meditere over døden, vil en derfor lære seg selv å kjenne. En vil bli seg sitt ansvar som menneske bevisst som et ubetinget ansvar for den annen. 
I dette kallet til å forholde seg til den annen som annen møtes den jødiske og den greske tenkningen som i sin forskjellighet stadig fortsetter å forstyrre hverandre i Derridas filosofi. Nettopp som forskjellige representerer de også en uro i hans lesning av kristne tekster, som Kierkegaards Frygt og Bæeven. Den handler om det forferdelige ansvar som Abraham påtar seg ved å skulle ofre sin sønn. Han bærer ansvaret, han alene, og i dette ansvar fremfor døden og overfor Gud oppdager han seg selv, sitt kall til å handle. Samtidig oppdager han det fryktelige ved dette ansvaret, konflikten mellom kjærligheten til sønnen og kjærligheten til Gud. En slik avgrunn møter ifølge Derrida enhver som etter Abraham kalles til å handle, til å foreta valg som ikke kan sikres, som får store konsekvenser for andre.

Det er dette kallet som er hemmeligheten ved alt som med rette kalles tro - religiøs eller ikke. Og skillet mellom tro og fornuft er ikke et skille mennesker kan trekke, ved f.eks. å utelukke troen fra sin rasjonalitet. Også grensen mellom tro og fornuft er derfor en grense som går tvers gjennom tenkningen. ${ }^{13}$ Troen representerer i likhet med galskapen dette fremmede, det andre, som vår rasjonelle evne aldri helt kan begripe, men heller aldri utelukke muligheten av.

Også døden er innskrevet i språket som et spor, en uvisshet som ikke kan forklares og ikke beskrives. Som det uforklarlige holder døden sin hemmelighet skjult, men representerer samtidig et kall til avgjørelse og ettertanke. Ved graven utløser den de etterlattes sorg og sorgens arbeid; tilegnelsen av det ugjenkallelige. Men dens spor i skriften er nettopp uttrykk for fraværet, for at forfatteren har mistet kontrollen over sin tekst og må overlate dens ulike betydninger til leseren. Allerede i Grammatologien (1967) påpekte Derrida at all skrift er testamentær, en gave testamentert fra forfatteren til en (ukjent) leser. Og som andre testamenter (nye og gamle) vitner den om dødens spor. I 2004 var det Jacques Derrida selv som skulle ta avskjed - og bli tatt avskjed med. Men tekstene han skrev fortsetter å forstyrre filosofien, forstyrre teologien og grensene mellom dem. Som det tvetydige ordet, det hverdagslige ordet som bærer en avgrunn i sin midte: Adieu. 


\section{Noter}

1 Jacques Derrida, De la grammatologie, 95.

2 Essayet er trykket i: Jacques Derrida, Marges de la philosophie (1972).

3 Jacques Derrida, Wie nicht sprechen. Verneinungen, 54-55.

4 Jacques Derrida, Wie nicht sprechen. Verneinungen, 76.

5 Den mest kjente kritikken av at Derrida gjør filosofi til teologi er skrevet av Dominique Janicaud i boken Le tournant théologique de la phénoménologie française (1991). Kritikken av Derridas teologiske anliggende kommer aller tydeligst fra radical orthodoxy, f.eks. hos John Milbank, men også fra en luthersk religionsfilosof som Ingolf Dalferth (se f.eks. artikkelen «Umsonst», i: Studia Theologica 59, 2005, 83-103).

6 Se Jacques Derrida, On the Name, 62-65.

7 Derrida spiller i denne sammenheng på det tvetydige i det tyske uttrykket «(sich) versprechen», nemlig at løftet aldri kan romme eller uttrykke oppfyllelsen, slik at den som ytrer løftet til enhver tid gjør seg skyldig i en forsnakkelse og en $u$ tsettelse.

8 Derrida siterer i denne sammenheng den tyske dikteren Angelus Silesius som skriver: «Geh hin, wo du nicht kanst; sih, wo du sihest nicht: Hör wo nichts schallt und klingt, so bistu wo GOtt spricht.» Jacques Derrida, On the Name, 44.

9 Se Jacques Derrida, On the Name, 71.

10 Se Jacques Derrida, On the Name, 70.

11 «The question-prayer which turned me toward him perhaps already shared in the experience of the à-Dieu with which I began. The greeting of the à-Dieu does not signal the end. 'The à-Dieu is not a finality', he says, thus challenging the 'alternative between being and nothingness', which 'is not ultimate.' The àDieu greets the other beyond being, in what is 'signified, beyond being, by the word 'glory." ( (Jacques Derrida, Adieu, 13).

12 Se Platon, Faidon 81a.

13 Sml. Jacques Derrida, Foi et savoir. 


\section{Litteratur}

Caputo, John D. The Prayers and Tears of Jacques Derrida. Indiana University Press, Bloomington/Indianapolis 1997

Dalferth, Ingolf U. «Umsonst», i: Studia Theologica 59, 2005, 83-103

Derrida, Jacques. De la grammatologie. Éditions de minuit, Paris 1967

- L'écriture et la différence. Éditions du Seuil, Paris 1967

- Marges de la philosophie. Éditions de minuit, Paris 1972

- Psyché: Inventions de l'autre, Éditions Galilée, Paris 1987

- Wie nicht Sprechen. Verneinungen. [Orig. Comment ne pas parler. Dénégations]

Overs. Hans-Dieter Gondek. Passagen-Verlag, Wien 1989

- Passions. Éditions Galilée, Paris 1993

- On the Name. Overs. David Wood, John P. Leavey Jr. og Ian McLeod. Stanford

University Press, Stanford, California 1995

- Gift of Death [Orig. Donner la mort]. Overs. D. Willis. Chicago University

Press, Chicago 1995

- Apories. Éditions Galilée, Paris 1996

- Adieu to Emmanuel Levinas. [Orig. Adieu, Éditions Galilée, Paris 1997] Overs.

Pascale-Anne Brault og Michael Naas. Stanford University Press, Stanford, California 1999

- Foi et savoir. Les deux sources de la "religion" aux limites de la simple raison.

Éditions du Seuil, Paris 2001

Dionysios Areopagita. Den mystiske teologi, i: Egil A. Wyller (utg.), Platonismehenologi $i$ antikk og middelalder. Solum forlag, Oslo 1993, 376-402

Haga, Joar. Om det Andre: Dekonstruksjon og negativ teologi. Jacques Derrida og hans resepsjon av Dionysios Areopagita. Spesialavhandling. Det teologiske Menighetsfakultet, Oslo 2000

Janicaud, Dominique. Le tournant théologique de la phénoménologie française.

Eclat, Paris, 1991

Mjaaland, Marius Timmann. Autopsia. Self, Death, and God after Kierkegaard and Derrida. deGruyter Verlag, Berlin/New York 2007 (kommer i januar; se www.degruyter.de)

Platon, Faidon, i: Platons Samlede Verker, bd. 4. Overs. Egil Kraggerud. Vidarforlaget, Oslo 2001 